\title{
Santa Maria di Agnano (Ostuni, Pouilles)
}

Donato Coppola, Martine Dewailly, Alessandro Quercia e Sergio González Sánchez

Università degli Studi di Bari Aldo Moro, University of Leicester, Soprintendenza per i Beni Archeologici della Puglia e Parco archeologico di S. Maria d'Agnano (ed.)

\section{(2) OpenEdition \\ Journals}

\section{Edizione digitale}

URL: http://journals.openedition.org/cefr/463

DOI: $10.4000 /$ cefr. 463

ISSN: 2282-5703

\section{Editore}

École française de Rome

\section{Notizia bibliografica digitale}

Donato Coppola, Martine Dewailly, Alessandro Quercia e Sergio González Sánchez, « Santa Maria di Agnano (Ostuni, Pouilles) », Chronique des activités archéologiques de l'École française de Rome [Online], Italie du Sud, Messo online il 19 décembre 2012, consultato il 02 août 2019. URL : http://

journals.openedition.org/cefr/463; DOI : 10.4000/cefr.463

Questo documento è stato generato automaticamente il 2 agosto 2019.

(c) École française de Rome 


\section{Santa Maria di Agnano (Ostuni, Pouilles)}

\section{Donato Coppola, Martine Dewailly, Alessandro Quercia e Sergio González Sánchez}

Università degli Studi di Bari Aldo Moro, University of Leicester, Soprintendenza per i Beni Archeologici della Puglia e Parco archeologico di S. Maria d'Agnano (ed.)

1 Le attività di scavo e indagini archeologiche nel 2011 si sono sviluppate lungo due ambiti di ricerca :

1. Una campagna di scavo concentrata in tre settori specifici, ossia nell'area $\mathrm{H}$, lungo la prosecuzione del ipotetico muro di peribolo del santuario identificato l'anno scorso, nella parte coperta del riparo (Esterno) antistante la grotta e nella terrazza inferiore verso mare (area L-M), in corrispondenza della lunga trincea aperta nella scorsa campagna di scavo.

2. Una campagna di prospezioni geofisiche nell'area del parco archeologico del santuario, volta per identificare la reale estensione del santuario ed eventuali strutture e/o installazioni, al fine di procedere ad indagini archeologiche mirate di verifica.

\section{La campagna di scavo}

\section{Area H (Donato Coppola)}

2 L'indagine stratigrafica condotta nel giugno 2011 si configura come un ampliamento dell'Area H, impostata nel corso della campagna di scavo del 2010 lungo il limite occidentale della zona santuariale per verificare la prosecuzione della probabile fondazione del muro di peribolo identificato l'anno scorso. L'équipe dell'Università di Bari è stata coordinata da Donato Coppola, dal dott. Nicola de Pinto (responsabile di saggio) e dal dott. Francesco Genchi (rilievo, restituzione grafica e informatica).

3 Il muro, con orientamento Nord / Sud si sviluppa per una lunghezza di circa m 9,30 ed è composto da blocchi calcarei di vario tipo, alcuni molto ben squadrati (a Nord), altri grossolanamente sbozzati. A Sud il muro, dopo l'ultimo masso di chiusura, volge a $90^{\circ}$ in 
direzione E / W e presenta un ribassamento strutturale dovuto, forse, a una soglia di accesso.

4 Il rinvenimento di un frammento di ceramica a vernice nera di IV secolo a.C., che si associa ai resti coevi rinvenuti in precedenza in uno strato di colore marrone chiaro, compatto, ricco di tegole e materiale ceramico di IV-III secolo a.C. ci orienta per una datazione della fondazione del probabile peribolo alla fase ellenistica del santuario. La successiva obliterazione della fondazione con una colmata di pietrame eterogeneo restituisce materiali ceramici d'età tardo repubblicana, con frammenti di un elemento ceramico databile al II secolo a.C. rinvenuti in dispersione nel riempimento.

5 Il livello superiore è interessato da una frequentazione medievale del XIII secolo, come ci documentano alcuni rinvenimenti monetali angioini in rame e la presenza di due staffe da cavaliere, una in bronzo e l'altra in ferro.

Fig. 1 - Ostuni. Area $\mathrm{H}$, fondazione del probabile peribolo Ovest d'età ellenistica.

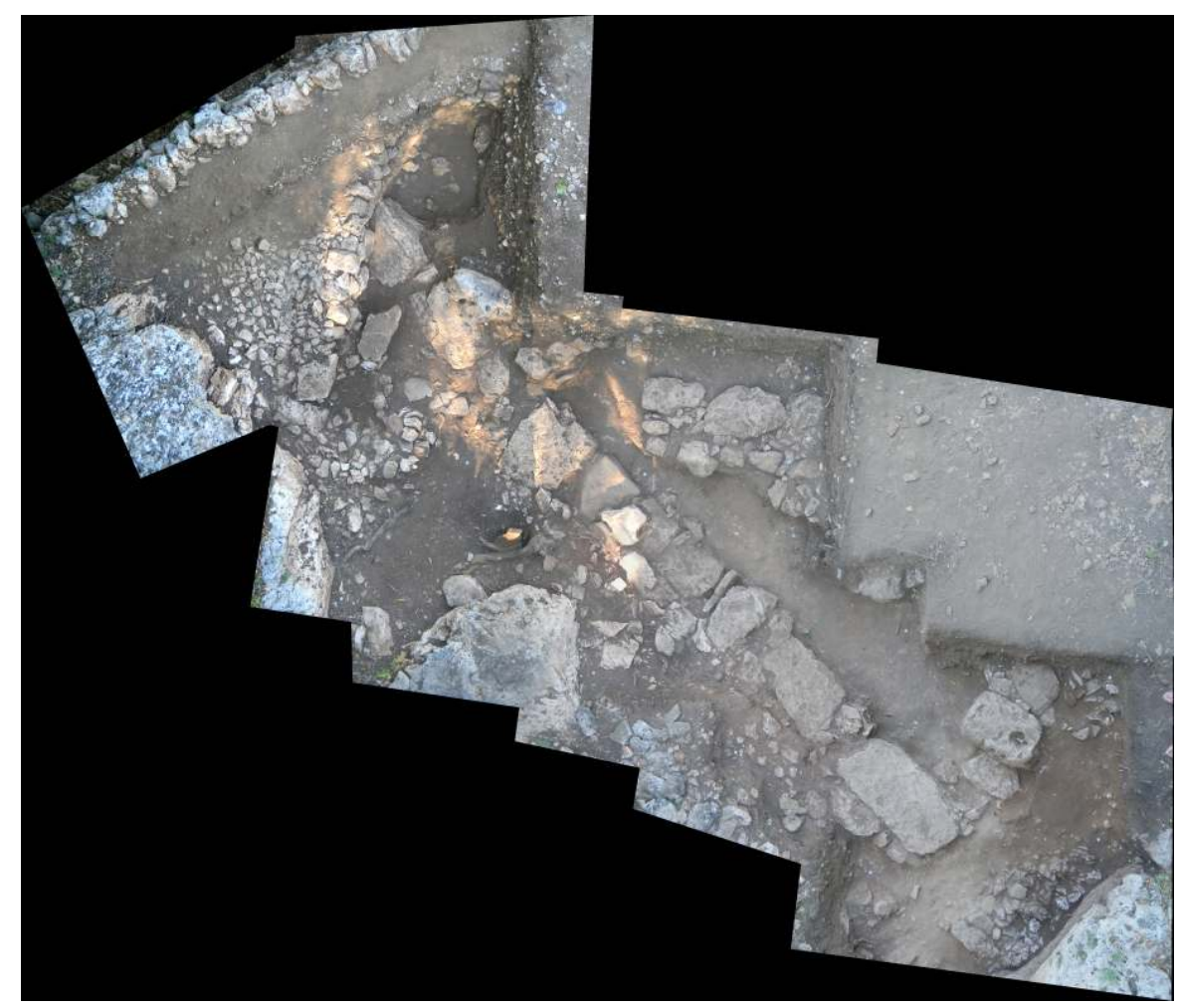

6 Di particolare interesse è l'aver verificato che per la posa dei massi calcarei della fondazione del peribolo Ovest si è operato un taglio in strati più antichi, addossando $i$ massi del recinto come un vero e proprio contenimento a Nord, mentre a Sud, superato il declivio, i massi sono a vista. L'impianto servì probabilmente per regolarizzare l'area in pendenza nel tratto che si addossa al grande riparo calcareo di Agnano. Gli strati più antichi restituiscono ceramiche tardo eneolitiche, industria litica neolitica, paleolitica e fauna pleistocenica, contenuti in una matrice di terreno rossastro che ostruisce la parte frontale interrata della retrostante cavità occidentale con materiali eterogenei nella parte superiore, schiettamente pleistocenici in quella inferiore. 


\section{Esterno 2}

7 Nell'area denominata Esterno 2, nella parte coperta del riparo di Agnano antistante la cavità orientale, Donato Coppola, coadiuvato dall'antropologa Francesca Epifani (scavo e studio antropologico) e da Giovanni Colucci (restituzione in calco) che coordinavano il gruppo di scavo dell'Università di Bari, hanno rinvenuto una sepoltura primaria con evidenti connessioni anatomiche, denominata Ostuni 7.

Fig. 2 - Ostuni. Esterno 2, sepoltura Ostuni 7 (XII-XIV sec. d.C.).

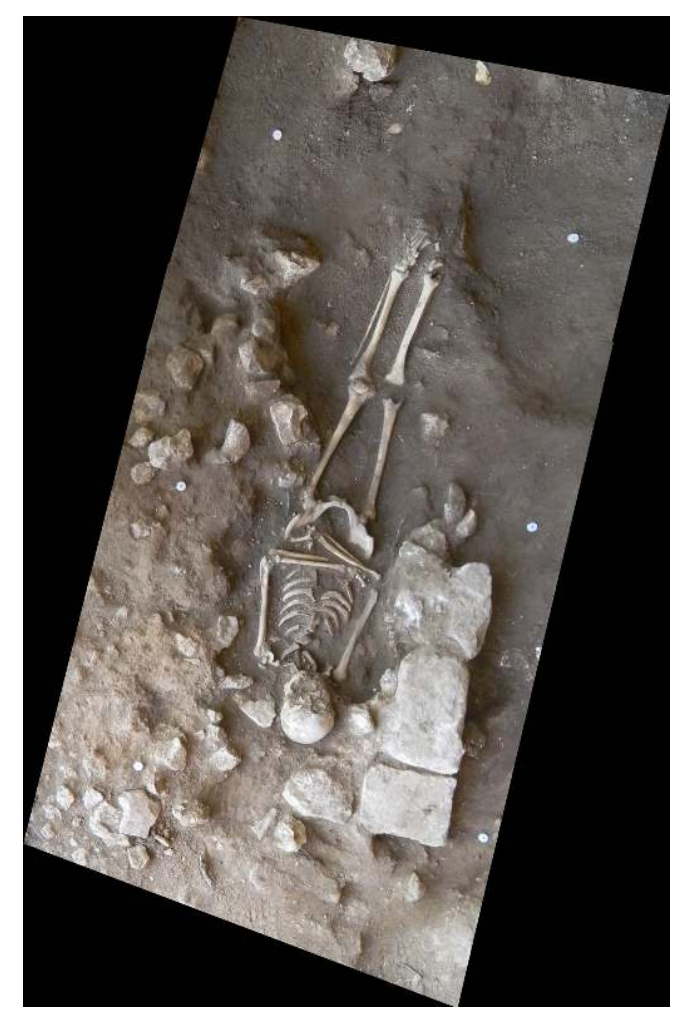

8 L'individuo fu interrato in una fossa di forma irregolare scavata nel terreno delimitata nel lato Ovest da tre grossi blocchi regolari probabilmente pertinenti alla sepoltura, ed era in posizione supina, con orientamento Nord Ovest, con il cranio leggermente inclinato a destra, gli arti superiori flessi sul torace e gli arti inferiori distesi. Il defunto è un individuo adulto maturo di sesso maschile, la cui statura stimata è di $175,08 \mathrm{~cm}$. I rilievi osteometrici e i relativi indici rivelano un cranio di forma allungata (indice cranico : 74,4 dolicocefalo), faccia stretta e lunga (indice facciale totale: 93,1 leptoprosopia; indice facciale superiore: 56 leptenia) apertura nasale bassa e larga (indice nasale: 70 ipercamerrino). Per quanto riguarda gli arti superiori gli omeri risultano robusti (indice di robustezza omero $\mathrm{dx}: 25,3$; omero $\mathrm{sx}$ : 25,4 ), le inserzioni muscolari sono molto sviluppate.

9 Nell'avambraccio destro e sinistro si osserva una situazione non omogenea a livello dell'ulna in quanto si rileva sia a $\mathrm{dx}$ sia a sx una robustezza gracile (indice di robustezza ulna $\mathrm{dx}$ : 18 ; ulna sx : 16). É stata riscontrata una differenza di robustezza per il radio. Il radio sinistro ha una robustezza media (indice di robustezza : 20), il radio destro risulta essere più robusto (indice di robustezza: 22). Le inserzioni muscolari sono poco sviluppate nel radio mentre sono molto sviluppate nell'ulna. 

robustezza forte (indice di robustezza : 12,6) mentre il femore sinistro ha una robustezza debole (indice di robustezza : 12,4). È stato possibile rilevare un pilastro debole nel femore destro (indice pilastrico : 106,6) e un pilastro medio nel femore sinistro (indice pilastrico : $114,28)$. Le inserzioni muscolari a livello degli arti inferiori sono poco sviluppate.

masticatoria. Si osservano forti atrofie alveolari che interessano soprattutto il mascellare, inoltre si sono riscontrate delle carie distruttive al livello mascellare nel canino dell'emiarcata destra mentre a livello mandibolare nel P1 dell'emiarcata sinistra e nell'M2 dell'emiarcata destra.

13 Non sono state riscontrate patologie. È da segnalare il particolare stato di conservazione della gabbia toracica. Le coste presentano nella loro parte più mediale una forte porosità dovuta probabilmente al contatto con una tavoletta lignea (della quale sono stati ritrovati pochi frammenti) posizionata sul defunto probabilmente al momento della morte. L'assenza di elementi di abbigliamento e le evidenze tafonomiche di Ostuni 7 ci indicano la probabile presenza di un sudario nel quale il corpo era stato avvolto. La stringente somiglianza con la tipologia del seppellimento di Ostuni 3 (Ns. Rif. LTL1810 : $762 \pm 40$ BP ; Calibrata : 1180-1300 AD, $95.4 \%$ ) ci orienta per una datazione di Ostuni 7 al XII-XIV secolo d.c.

\section{Esterno}

14 Nell'area antistante l'ingresso della cavità orientale sono proseguite le indagini stratigrafiche (già iniziate nel 1991) a cura di Donato Coppola e del dott. Francesco Genchi che coordinava l'équipe dell'Università di Bari. Dopo la sequenza di livelli riferibili alle frequentazioni epigravettiane comprese tra 17640 - $17380 \mathrm{cal} \mathrm{BC}$ e 9700 - $9290 \mathrm{cal}$ BC, con una serie di interventi umani consistenti nello scavo di fosse di combustione relative alla frequentazione del riparo, sono stati indagati i livelli gravettiani sia nella parte soprastante i crolli calcarei, sia in quella sottostante, con il rinvenimento anche di industria litica più antica di tipologia aurignaziana.

\section{Area M-L (Martine Dewailly, Alessandro Quercia)}

Nel mese di giugno è proseguito lo scavo del sondaggio, aperto nel 2010 (fig. 3), condotto da Martine Dewailly e Alessandro Quercia, con la collaborazione di studenti dell'Università di Bari ${ }^{1}$, specializzandi dottorandi dell'Università di Leicester (Regno Unito) e della Virginia (USA). 
Fig. 3 - Ostuni. Pianta generale del sito.

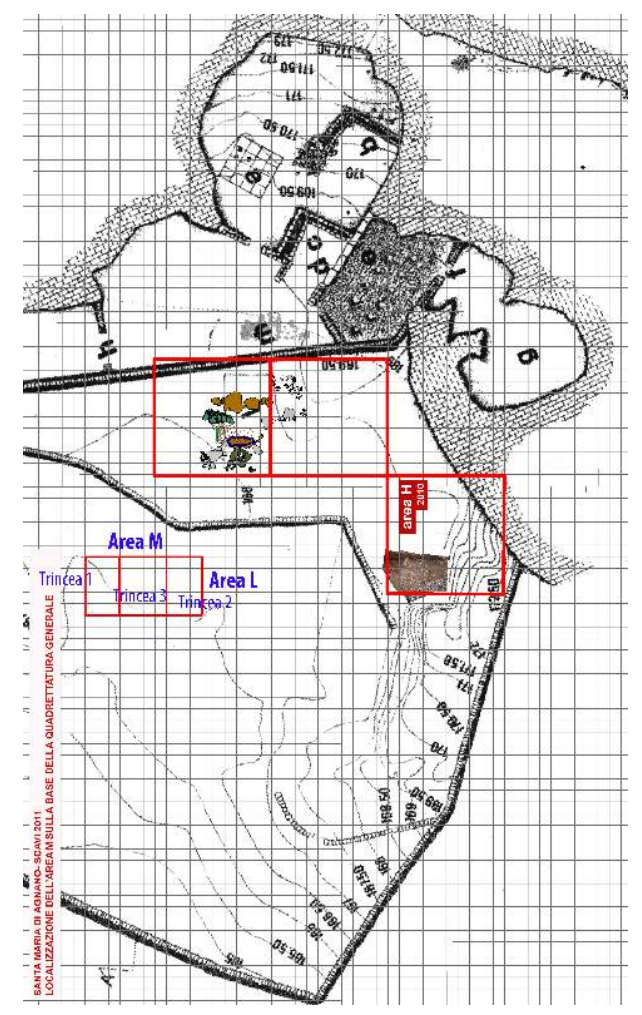

Si è proceduto all'approfondimento della trincea 1, aperta l'anno scorso, per evidenziare strutture o installazioni pertinenti al santuario di età messapica ed all'allargamento verso Ovest dello scavo in estensione (trincee 2 e 3 ).

Nelle tre trincee, sono stati asportati degli spessi strati di natura agricola, caratterizzati da terreno bruno, poco compatti e piuttosto polverosi, con poche pietre e scarso materiale ceramico, per lo più di età medievale e post-medievale, con una certa frequenza di residui di età classica. Gli strati agricoli, come anche i livelli sottostanti, sono digradanti da Sud verso Nord, ossia da monte a mare, presentando quindi una leggera variazione di quote.

Seguono dei livelli caratterizzati da un terreno molto soffice, privo di pietre, con scarsi materiali ceramici ridotti in frammenti di piccole dimensioni. L'analisi preliminare dei materiali sembra documentare l'assenza di materiale medievale e post medievale, l'abbondanza di ceramica ellenistica con qualche frammento di età arcaica e tardoarcaica, e pochi ma significanti frammenti di età tardo-antica (pareti di anfore LR 1 e 2, frammenti di sigillate africane). Si potrebbe ipotizzare che questi livelli siano da riferire allo sfruttamento intensivo dell'area a uso agricolo in età tardo-antica (V-VIII sec. d.C.), come testimonia la consistenza soffice del terreno e l'assenza di pietre.

Nella trincea 1, segue uno strato scuro con una certa quantità di pietre e tegole che copre direttamente un potente crollo di tegole e spezzoni di pietre irregolari che si estende per tutta la trincea (fig. 4). 
Fig. 4 - Ostuni. Area M, trincea 1, il crollo composto di pietre e tegole.

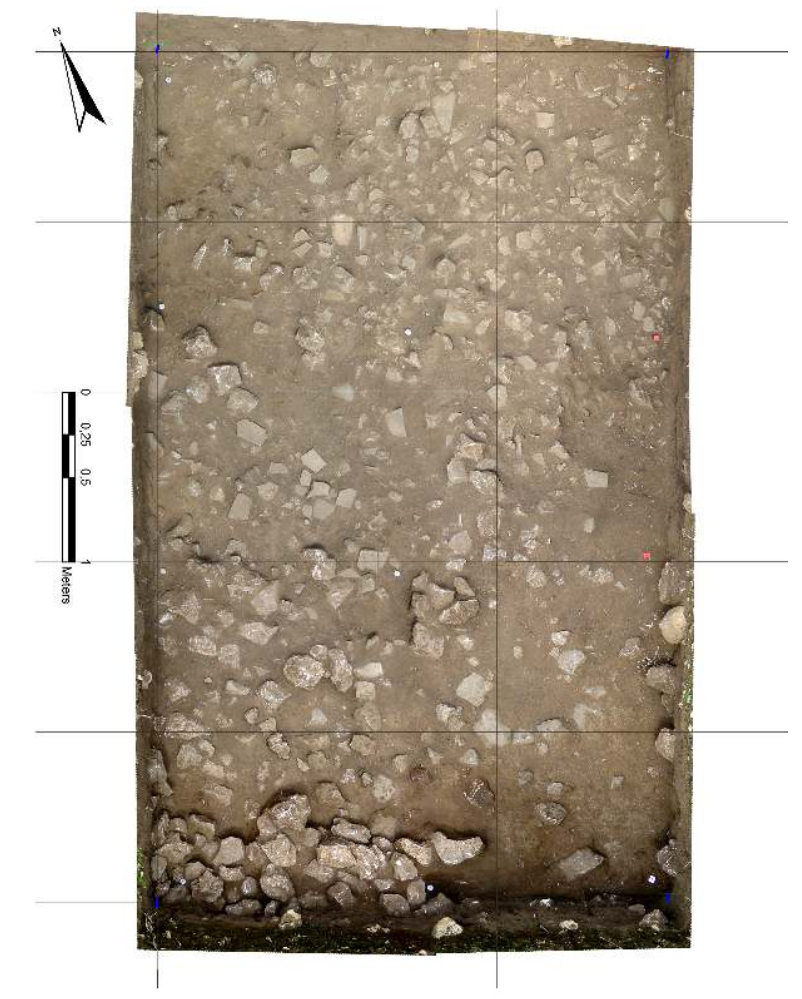

Lo strato scuro ha restituito una buona quantità di materiale ceramico (vernice nera, ceramica acroma e verniciata di tipo messapico, ceramica a pasta grigia) che si colloca prevalentemente in un arco cronologico tra la fine del IV e la prima metà del II sec. a.C. Significativi a tal proposito sono i frammenti di ceramica a pasta grigia, un piatto vernice nera tipo K02b e un kantharos tipo K44b (secondo la tipologia proposta da Yntema per il materiale di Valesio) che sembrano collocare la formazione dello strato a non prima della fine del III-inizi II a.C. Tale datazione fornisce un preliminare terminus ante quem, per la cronologia del crollo individuato su tutta l'area della trincea. Il crollo si caratterizza per la presenza di tegole concentrata soprattutto verso la metà settentrionale della trincea, ossia verso il mare, mentre nella parte meridionale - ossia verso la grotta - il crollo è composto quasi esclusivamente da spezzoni irregolari di pietra di medie e piccole dimensioni e prosegue oltre la sezione. A livello ipotetico, potrebbe trattarsi del crollo di unica struttura. La marcata differenza, tra la parte del crollo con tegole e quella con pietre, sembra poter suggerire che le tegole furono il primo elemento a cadere nel collasso dell'ipotetica struttura, mentre gli spezzoni di pietra sono da riferirsi al crollo dell'elevato della stessa struttura. Gli elementi cronologici forniti dai materiali rinvenuti nello strato soprastante sembrano poter affermare che la struttura possa essere datata non oltre la media età ellenistica (fine III sec a.C.) e che quindi possa essere considerata parte integrante del santuario messapico. Il crollo prosegue verosimilmente verso monte.

Nella trincea centrale 3, sono stati asportati solo gli strati agricoli medievali e post medievali.

Nella trincea 2 - area $\mathrm{M} / \mathrm{L}$, sotto gli strati agricoli, si riscontra uno strato di terra più scura che ha restituito un abbondante materiale ceramico prevalentemente collocabile 
nell'età ellenistica ma anche più recente, indicando la formazione di questo strato forse in età tardo-antica. Alla stessa quota, è stato individuato, limitatamente all'estremità sud della trincea, uno strato con poche pietre e tegole di dimensioni più piccole rispetto al crollo della trincea 1 , che fa pensare ad un contesto di natura differente; nel resto della trincea prosegue lo strato scuro. Entrambe questi strati coprono un livello molto compatto, ricco di carboncini e tracce di bruciato, specialmente su pietre. Dalla pulizia superficiale, provengono alcuni reperti in bronzo - una punta di lancia e una pinzetta da toeletta - e un frammento di piatto a vernice nera che trova confronti con il tipo Yntema K03C documentato a Valesio (270/50-200 a.C.). Si tratta verosimilmente di un piano di frequentazione di un'area aperta probabilmente risalente alla fase medio-ellenistica del santuario, pressoché nella stessa fase del crollo nella trincea 1, e gli oggetti bronzei rinvenuti sono da ritenere dediche votive, probabilmente in giacitura secondaria, che rientrano in categorie già documentate nel santuario di Santa Maria d'Agnano.

\section{Geophysical survey (Sergio González Sánchez)}

In the fieldwork campaign of June 2011 a geophysical survey of the site of Santa Maria di Agnano in Ostuni (Italy) was carried out as part of the strategy to approach this complex site, in order to have a better and wider knowledge of its topographical context, to plan systematically a site strategy for the future through the location of areas for further excavation, and most importantly to define the real extent of the ancient sanctuary ${ }^{2}$. The survey was carried out by a team of MA and PhD students from the School of Archaeology and Ancient History of the University of Leicester who would ultimately make the survey and process the data collected ${ }^{3}$. The equipment used for the geophysical survey was a resistivity meter ${ }^{4}$. This equipment consists on two pairs of probes connected to a main unit which reads the data produced by those probes. Basically, this technique is characterized by the emission of electrical signals from one pair of probes and the reception of this signal by the other pair of probes, measuring on its way the resistivity encountered in the soil and sending that information to the main unit. Resulting data in Ohms is transformed into images through the use of geospatial software. A higher resistivity would appear in a darker scale while a low resistivity would appear as a lighter tone. Higher resistivity can possibly mean the appearance of structures, rocks or other materials. Thus, data collected from the surface can be used for mapping subsurface archaeological features in a non invasive way, preserving the site from unnecessary destructions and helping the archaeologists to design a more effective site strategy.

Initially, the group decided to take a classical approach to the survey by creating a continuous grid. As soon as the team arrived on site it was immediately realized that the nature of the landscape (terraced hill) and the composition of the soil (extremely rocky in most areas) made that classical approach useless. It was decided then that separate surveys would be made for different terraces creating a puzzle that needs to be resolved in order to get general conclusions (fig. 5). 
Fig. 5 - Ostuni. Part of the team from the University of Leicester doing the geophysical survey with the resistivity meter.

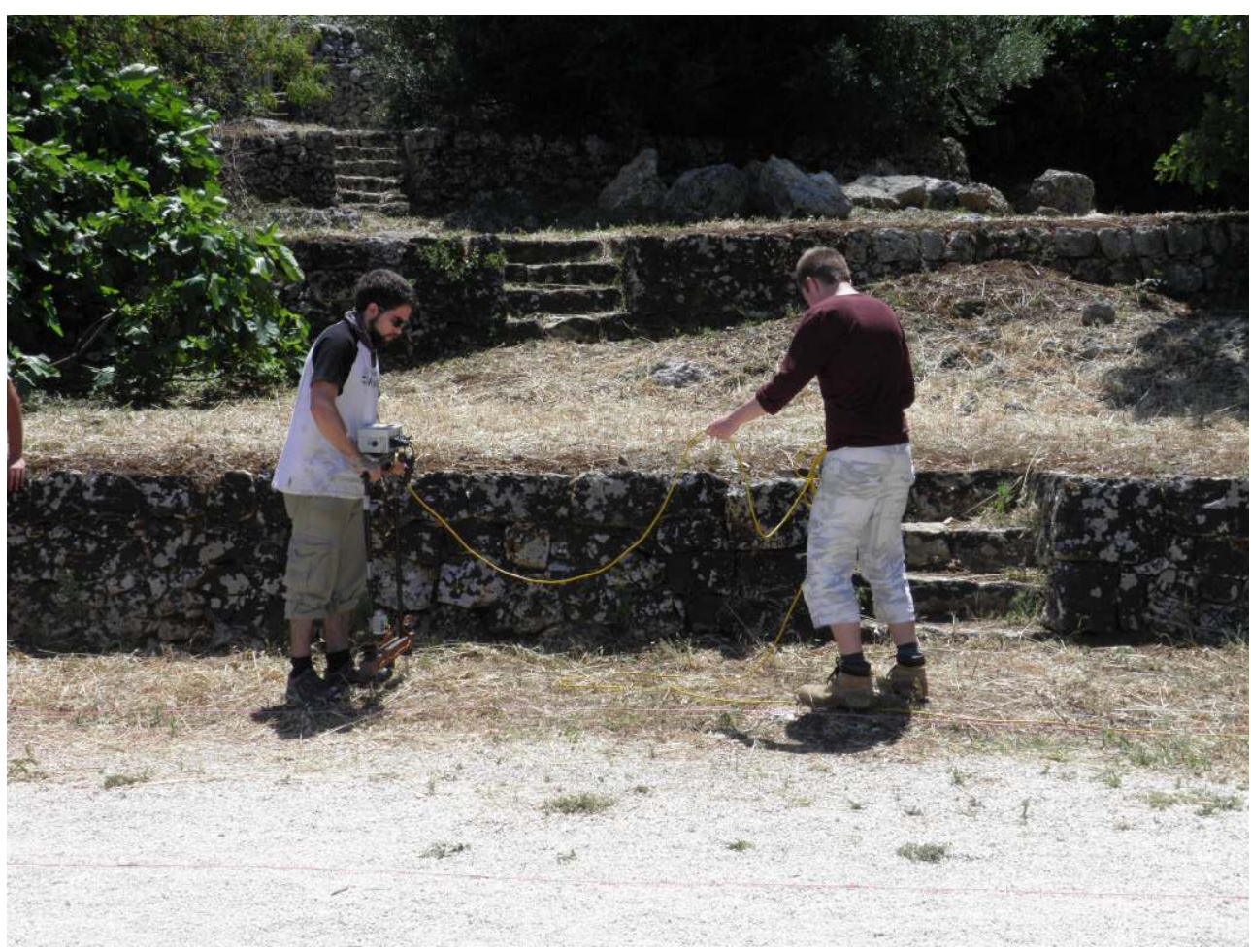

26 Topographically, the site is characterized by the existence of two well differentiated areas: an upper multi-terraced area, where most part of the archaeological features and evidences were unearthed and a lower plain area, where the facilities of the modern archaeological site of Santa Maria di Agnano are located.

\section{Preliminary results (fig. 6)}

\section{Upper multi-terraced area}

The main characteristic of this area is the presence of relevant quantities of scattered rocks and visible bedrock, which makes very difficult the take of measurements through the technique of resistivity and produces very high readings not related to the existence of earthen structures at all. However, the results thrown by the equipment are revealing. 
Fig. 6 - Ostuni. General topographical map of the upper multi-terraced area of Santa Maria di Agnano, with the geophysical images of the areas surveyed and mentioned in this text.

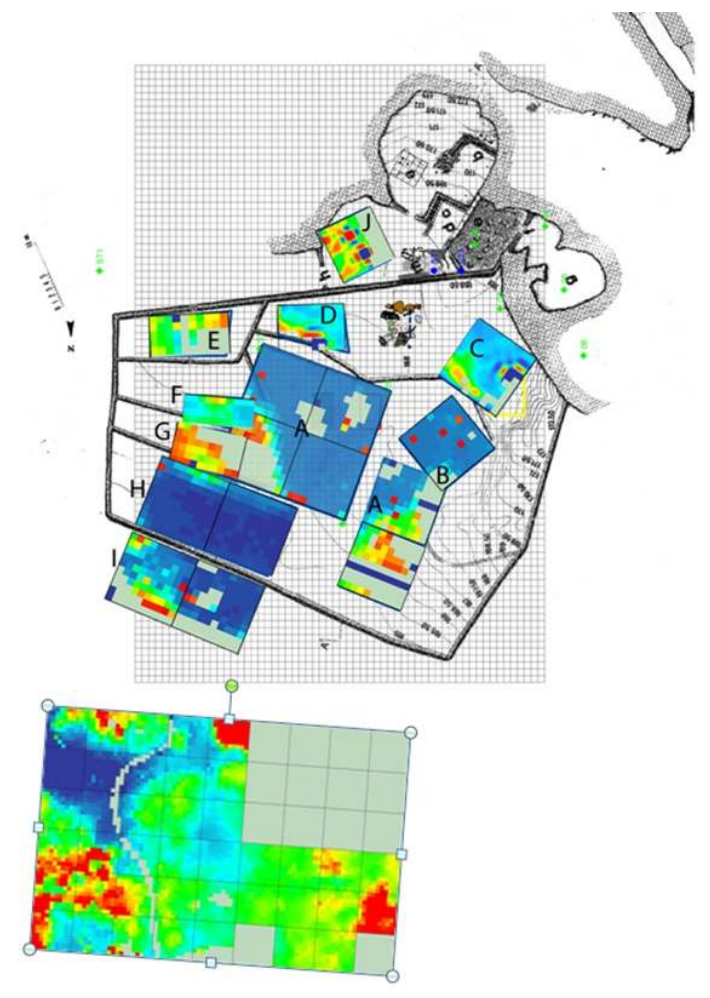
Santa Maria d'Agnano', set in the last years: a ticket office, some stores, a parking area, a modern amphitheatre and the reconstruction of a prehistoric hut. In topographical terms, this terrain is larger and flatter than the multi-terraced upper area and therefore the survey in this area resulted much easier to complete, although the nature of the soil still very rocky. The survey threw some interesting results here although the data needs 
to be studied in detail in order to come to a firm conclusion: a structure, characterised likely by two orthogonal walls has been located in the North-Western corner of the area surveyed, and another wall, with the same orientation, seems to be detected nearby. Preliminary interpretation, based on the shape unearthed by the images resulting from the geo-physical survey, suggests this may well be the remains of a building not yet well identified.

The connection between the two areas is not confirmed yet and further research needs to be carried out to get firm conclusions. However, the proximity of the located structures in both areas, strongly suggests a constant use of this area, with its epicentre in the sanctuary by/within the cave.

\section{NOTE}

1. Oltre alle indagini archeologiche sono state eseguite attività di post-scavo e laboratorio presso il museo per le Civiltà preclassiche di Ostuni, in particolare il lavaggio, la siglatura e la classificazione dei reperti rinvenuti durante la campagna di scavo, che hanno visto la partecipazione attiva degli studenti coinvolti nello scavo.

2. We are grateful to the Director of the excavations and research project at Santa Maria d' Agnano, Prof. Donato Coppola (Università di Bari) for inviting us to do the geophysical survey of the site. We would like also to thank Martine Dewailly (École française de Rome) and Alessandro Quercia (University of Leicester-Soprintendenza per i beni archeologici del Piemonte e Museo antichità egizie), coordinators of the excavation of the classical sanctuary, for their advice and support.

3. The survey team was formed by Flavio Bacci, Sergio Gonzalez Sanchez, Lee Antonio Grana, Marcella Raiconi and David Walsh. We are especially grateful to Dr Jeremy Taylor (University of Leicester) who kindly trained the team and supported it towards the interpretation of the data with much advice and suggestions

4. Model: RM 15. The equipment was kindly borrowed by the University of Leicester. The travel insurance of equipment and team staff involved in the survey was financially supported by the School of Archaeology and Ancient History (University of Leicester); we are grateful to Dr Neil Christie for the support in obtaining the travel insurances.

5. Dr Jeremy Taylor, pers. communication

\section{INDICE}

institutions Parc archéologique de S. Maria d'Agnano, University of Leicester, Soprintendenza per i Beni Archeologici della Puglia

Mots-clés : sépulture, occupation médiévale, sanctuaire, influence hellénistique 


\section{AUTORI}

DONATO COPPOLA

Università degli Studi di Bari Aldo Moro - donato.coppola[at]libero.it

MARTINE DEWAILLY

École française de Rome - martine.dewailly[at]efrome.it

\section{ALESSANDRO QUERCIA}

University of Leicester - aq15[at]leicester.ac.uk

SERGIO GONZÁLEZ SÁNCHEZ

University of Leicester - sg290[at]leicester.ac.uk 